\title{
Moisture Sorption Isotherm and Thermodynamic Properties of Jamun (Syzygium cumini L.) Powder made from Jamun Pulp and Seed
}

\author{
Indira Dey Paul ${ }^{\mathrm{a}}$ And Madhusweta Das ${ }^{\mathrm{a}^{*}}$ \\ a Agricultural and Food Engineering Department, Indian Institute of Technology Kharagpur, Pincode-721302, \\ West Bengal, India \\ ${ }^{*}$ Corresponding author \\ madhu@agfe.iitkgp.ac.in \\ TEL: +918777359497 \\ FAX: +91 3222 282244; 255303
}

Received: 10 July 2018; Published online: 18 April 2019

\begin{abstract}
The present work aimed to: i) find the suitable proportion, based on sensory evaluation, of microwave-convective hot air dried jamun (Syzygium cumini L.) pulp and seed kernel powder to be mixed for the preparation of jamun powder (JP); ii) generate and model the moisture sorption isotherm (MSI) of JP; and iii) estimate net isosteric heat of sorption $\left(\mathrm{q}_{s t}\right)$, spreading pressure $(\Phi)$, net integral enthalpy $\left(\mathrm{Q}_{i n}\right)$, and net integral entropy $\left(\mathrm{S}_{i n}\right)$. To formulate JP, the proportion $(\mathrm{w} / \mathrm{w}, \mathrm{db})$ comprising $2 \%$ kernel and $98 \%$ pulp powder was the most desirable. The Peleg model was the best fit to MSI of JP. The $\mathrm{q}_{s t}$ decreased following linear relationship from $11.02 \mathrm{~kJ} \mathrm{~mol}^{-1}$ at $5 \%$ equilibrium moisture content (EMC) to $0.27 \mathrm{~kJ}^{-\mathrm{mol}^{-1}}$ at $30 \%$ EMC. The $\Phi$ increased with increase in water activity and decreased with increase in temperature from $25{ }^{\circ} \mathrm{C}$ to $35{ }^{\circ} \mathrm{C}$, and the values of $\Phi$ at $45{ }^{\circ} \mathrm{C}$ were even higher than at $25^{\circ} \mathrm{C}$. Net integral enthalpy $\left(\mathrm{Q}_{i n}\right)$ initially decreased till $6 \%$ moisture content in JP and displayed an increasing trend with further increase in moisture content. On the contrary, $\mathrm{S}_{i n}$ kept on decreasing continually with increasing moisture content. The moisture zone of $7-11 \%$ was considered safe for storage of JP within the temperature range of $45-25{ }^{\circ} \mathrm{C}$.
\end{abstract}

Keywords: Jamun powder; Moisture sorption isotherm; Net isosteric heat of sorption; Spreading pressure; Net integral enthalpy; Net integral entropy

\section{Introduction}

Jamun (Syzygium cumini L.), a type of berry with an attractive sweet-sour taste and purple colour, is a fruit native to India and East Indies, but is also found in other countries like Thailand, Philippines and Madagascar. All the fractions of whole jamun fruit, besides their nutritional constituents, contain a lot of phytochemicals and, hence, are widely popular for their medicinal values. Sehwag and Das (2015) reported a broad classification of the phytochemicals such as anthocyanins, phenolic acids, flavonols, flavanonols, carotenoids and terpenes in the pulp and skin, and alkaloids, flavonoids, glycosides, phytosterols, saponins, tannins and triterpenoids in the seed. Recent studies on jamun pulp and skin have established many therapeutic properties such as antidiabetic, antioxidant, hepatoprotective, antibacterial and anticancerous. Jamun seed kernel is richer in medicinal properties than pulp and skin, and possesses a range of pharmacological actions (Sehwag \& Das, 2015, 2016). However, due to its short seasonal availability 


\begin{tabular}{|c|c|c|c|}
\hline \multicolumn{4}{|c|}{ Nomenclature } \\
\hline$a_{m}$ & Surface area of a water molecule $\left(\mathrm{m}^{2}\right)$ & MSI & Moisture sorption isotherm \\
\hline $\mathrm{a}_{w}$ & Water activity & $\mathrm{Q}_{\text {in }}$ & Net integral enthalpy $\left(\mathrm{kJ} . \mathrm{mol}^{-1}\right)$ \\
\hline$\Phi$ & Spreading pressure $\left(\mathrm{J} \mathrm{m}^{-2}\right)$ & $\mathrm{q}_{s t}$ & Net isosteric heat of sorption (kJ. \\
\hline $\mathrm{a}_{w}^{*}$ & Geometric mean water activity at con- & & $\left.\mathrm{mol}^{-1}\right)$ \\
\hline EMC & $\begin{array}{l}\text { stant } \Phi \\
\text { Equilibrium moisture content }(\%, \mathrm{db})\end{array}$ & $\mathrm{R}$ & $\begin{array}{l}\text { Universal gas constant (kJ. } \mathrm{mol}^{-1} \text {. } \\
\mathrm{K}^{-1} \text { ) }\end{array}$ \\
\hline GMS & Glycerol monostearate & $\mathrm{r}^{2}$ & Co-efficient of determination \\
\hline $\mathrm{JP}$ & Jamun powder & $\mathrm{RH}$ & Relative humidity (\%) \\
\hline $\mathrm{K}_{\beta}$ & Boltzmann constant $\left(\mathrm{J} . \mathrm{K}^{-1}\right)$ & RMSE & Root mean square error \\
\hline LDPE & $\begin{array}{l}\text { Low density polyethylene } \\
\text { Least siønificant difference }\end{array}$ & $\mathrm{S}_{\text {in }}$ & Net integral entropy $\left(\mathrm{kJ} . \mathrm{mol}^{-1} \cdot \mathrm{K}^{-1}\right)$ \\
\hline $\mathrm{M}$ & $\operatorname{EMC}(\%, \mathrm{db})$ of the sample & $\mathrm{SD}$ & Standard deviation \\
\hline $\mathrm{MCD}$ & Microwave-convective hot air drying & $\mathrm{T}$ & Absolute temperature $(\mathrm{K})$ \\
\hline MD & Maltodextrin & TCP & Tricalcium phosphate \\
\hline MRE & Mean residual error $(\%)$ & $\mathrm{Z}$ & Integration constant \\
\hline
\end{tabular}

and highly perishable nature, jamun remains underutilized.

Removal of moisture by quick and efficient drying is the most promising way for seasonal and perishable fruits to be made available throughout the year. Dehydrated fruit in powder form can be incorporated within a variety of recipes, like desserts, biscuits and spreads, to add case specific flavor and functionalities without the moisture and volume of fresh fruit. Among different methods, a hybrid technique, microwave-convective hot air drying (MCD) has been used effectively for drying various food materials such as apricot halves (Horuz, Bozkurt, Karatas, \& Maskan, 2017), button mushrooms (Das \& Arora, 2018), oyster mushrooms (Bhattacharya, Srivastav, \& Mishra, 2015), okra (Kumar, Prasad, \& Murthy, 2014) and garlic cloves (Sharma \& Prasad, 2001). Prolonged exposure in conventional hot air drying leads to undesirable changes in product quality. Combining microwave with convective hot air can signifi- cantly reduce the drying time and improve product quality (Schiffmann, 1992). Although jamun seed powder (no mention of the presence or absence of seed coat) is available as an ayurvedic medicine for control of diabetic mellitus, technical information on drying of jamun seed and pulp is scanty in the literature. Recently Dey Paul and Das (2017) produced free flowing jamun pulp (along with skin) powder containing maltodextrin (MD, $12.2 \%$ ), tricalcium phosphate (TCP, $0.4 \%$ ) and glycerol monostearate (GMS, $1.4 \%$ ) on a dry basis (db) of pulp-skin, using MCD at $70{ }^{\circ} \mathrm{C}, 1$ watt. $\mathrm{g}^{-1}$ (W. $\mathrm{g}^{-1}$, power density), 0.5 m. $\mathrm{s}^{-1}$ air velocity, to maximally maintain its antioxidant activity. Monica, Dey Paul, and Das (2016) also observed that MCD $\left(60{ }^{\circ} \mathrm{C}, 2 \mathrm{~W}\right.$. $\left.\mathrm{g}^{-1}, 0.5 \mathrm{~m} . \mathrm{s}^{-1}\right)$ of jamun seed retained maximum antioxidant activity of its kernel. Thus, if pulp powder is mixed with seed kernel powder (bitter in taste probably due to the presence of saponins and tannins) (Kamal, 2014; Kapoor \& Iqbal, 2013) in a sensorially acceptable ratio, 
the mixture could be used as jamun powder (JP) for food purpose, with more health benefits than that of pulp powder alone.

Moisture sorption tendency, which depends on relative humidity $(\mathrm{RH})$ and temperature, is a major criterion in maintaining quality of fruit powders during handling and storage. Moisture sorption isotherm (MSI) provides the relationship between equilibrium moisture content (EMC) and its water activity $\left(\mathrm{a}_{w}\right)$ when the food equilibrates in air with different RHs at a certain temperature. On equilibration, the $\mathrm{a}_{w}$ of food (relates to stability) equals the $\mathrm{RH}$ of environment (Al-Muhtaseb, McMinn, \& Magee, 2002). Moisture sorption isotherm (MSI) is an essential tool in design of drying, packaging and storage of food. Mathematical modelling enables generation of MSI at any unknown temperature within the temperature range for which the MSIs have already been developed empirically. de Santana et al. (2015) reported MSIs of freeze dried jamun pulp (without skin) containing no additives. Biswal, Mohapatra, Panda, and Dash (2017) modelled the desorption isotherm of fresh jamun fruits. Ferrari, Marconi Germer, Alvim, Vissotto, and de Aguirre (2012) modelled the MSI of spray dried blackberry (Rubus species) powder containing maltodextrin and gum arabic. Information on the MSI of powder containing pulp, skin and kernel of jamun, together with any drying aid (to make the powder form) is not available.

Moisture sorption isotherms at different temperatures are used to evaluate thermodynamic parameters like net isosteric heat of sorption $\left(\mathrm{q}_{s t}\right)$, spreading pressure $(\Phi)$, net integral enthalpy $\left(\mathrm{Q}_{\text {in }}\right)$ and net integral entropy $\left(\mathrm{S}_{\text {in }}\right)(\mathrm{Al}-$ Muhtaseb, McMinn, \& Magee, 2004). The $\mathrm{q}_{s t}$ (total heat of sorption for binding water vapor on sorbent less than the heat of vaporization of pure water, at the system moisture content) determines moisture-sorbent binding strength, and is required in designing equipment for dehydration processes as well as prediction of $\mathrm{a}_{w}$ when the food is stored at fluctuating temperature (Chowdhury \& Das, 2010). Spreading pressure $(\Phi)$, the difference in surface tension between bare sorption sites of the sorbent and sites with adsorbed molecules, indicates the free surface energy of adsorption (Al-Muhtaseb et al., 2004).
Net integral enthalpy $\left(\mathrm{Q}_{\text {in }}\right)$ at constant $\Phi$, a measure of the strength of moisture-solid binding, is used to determine $\mathrm{S}_{\text {in }}$ (McMinn \& Magee, 2003). Net integral entropy $\left(S_{i n}\right)$ explains the degree of disorder and randomness of the adsorbed water molecules (Arslan \& Togrul, 2005; Igathinathane, Womac, Sokhansanj, \& Pordesimo, 2007), and helps to determine the moisture at which the sorbent is stable.

Based on the above knowledge, the objectives of the present work were to: i) find the suitable proportion of pulp (with skin) and kernel powder to be mixed for preparation of JP; ii) generate and model the MSI of JP; and iii) estimate the thermodynamic parameters, including net isosteric heat of sorption $\left(\mathrm{q}_{s t}\right)$, spreading pressure $(\Phi)$, net integral enthalpy $\left(\mathrm{Q}_{i n}\right)$ and net integral entropy $\left(S_{i n}\right)$ for the JP.

\section{Materials and Methods}

\section{$2.1 \quad$ Material}

Fully matured jamun fruit (raw material), apparently free from any damage, was procured from the local market of IIT Kharagpur, India. About $75 \%$ of the fruit was comprised of pulp with adherent skin (hereunder called pulp), with the remaining $25 \%$ being the seed. The moisture, protein, fat, ash, crude fiber and carbohydrate content of pulp were analysed and found to be $83.04 \pm 0.10 \%$ (wet basis, wb), $8.59 \pm 0.07$, $3.23 \pm 0.39,4 \pm 0.001,2.49 \pm 0.00$ and $81.71 \pm 0.45 \%$ (dry basis, db) respectively. For seed kernel, the respective values were $15.12 \pm 0.04 \%$ (wb), $5.90 \pm 0.14,1.01 \pm 0.01,2.34 \pm 0.02,2.33 \pm 0.37$ and $88.41 \pm 0.53 \%$ (db) (Sehwag \& Das, 2016). MD (dextrose equivalent $<20$ ) and TCP, both from HiMedia Laboratories Pvt. Ltd., Mumbai, India, and GMS from Alfa Aesar, Massachusetts, USA, were used as additives for production of pulp powder. Analytical grade lithium chloride $(\mathrm{LiCl})$, potassium acetate $\left(\mathrm{CH}_{3} \mathrm{COOK}\right)$, magnesium chloride $\left(\mathrm{MgCl}_{2}\right)$, potassium carbonate $\left(\mathrm{K}_{2} \mathrm{CO}_{3}\right)$, magnesium nitrate $\mathrm{Mg}\left(\mathrm{NO}_{3}\right)_{2}$, sodium nitrate $\left(\mathrm{NaNO}_{3}\right)$, sodium chloride $(\mathrm{NaCl})$ and potassium chloride $(\mathrm{KCl})$ were used to adjust $\mathrm{RH}$ (described below). All the chemicals were used as received. Glass distilled water was used for 
preparation of salt solutions.

\subsection{Preparation of raw materials}

The fruits were washed with potable water and air dried at room temperature. The pulp was separated from the seed with a knife, and stored in low density polyethylene (LDPE) pouches (about $250 \mathrm{~g}$ pouch $^{-1}$; pouch film thickness $0.05 \mathrm{~mm}$ ) at $-30{ }^{\circ} \mathrm{C}$. The seeds were washed with water to remove any adhering pulp, and similarly packed and stored.

\subsection{Preparation of jamun pulp and seed kernel powder}

The frozen pulp was put in an empty glass beaker, which was then thawed in a water bath at room temperature $\left(28{ }^{\circ} \mathrm{C}\right)$. The thawed mass was then ground into paste (at same temperature) using domestic grinder (Sumeet Research and Holdings Limited, Chennai, India). The paste was mixed with $12.2 \% \mathrm{MD}, 0.4 \% \mathrm{TCP}$ and $1.4 \%$ GMS on dry basis (db) of the pulp. The mixed paste was dried using a fully controlled miniature conveyer type industrial microwaveconvective hot air dryer (Enerzi Microwave Systems Pvt. Ltd., Bangalore, Karnataka, India) having $20-100 \mathrm{~kg} . \mathrm{h}^{-1}$ drying capacity, 2450 $\mathrm{MHz}$ frequency and 250-3000 W power. An inbuilt heater of $6 \mathrm{~kW}$ provided hot air $\left(25^{\circ} \mathrm{C}\right.$ to $200{ }^{\circ} \mathrm{C}$ ) circulation. The drying chamber, $2 \mathrm{~m}$ x $300 \mathrm{~mm}$ x $200 \mathrm{~mm}$, was made of $2 \mathrm{~mm}$ thick stainless steel. Drying was carried out at $70{ }^{\circ} \mathrm{C}$, $1 \mathrm{~W} \cdot \mathrm{g}^{-1}$ and $0.5 \mathrm{~m} . \mathrm{s}^{-1}$ air velocity. The composition of the mixture and drying method and conditions were described earlier (Dey Paul \& Das, 2017; Paul \& Das, 2018). The dried pulp obtained in flake form was ground into fine powder (212 $\mu \mathrm{m}$ passing).

The frozen jamun seeds were thawed, dried using the same dryer but at $60^{\circ} \mathrm{C}, 2 \mathrm{~W} . \mathrm{g}^{-1}$ and $0.5 \mathrm{~m}$. $\mathrm{s}^{-1}$ air velocity, and the seed coat was manually removed (Monica et al., 2016). The dried kernels were ground into fine powder $(212 \mu \mathrm{m}$ passing $)$. To judge the functionality, in separate work (not included here), total phenolic content (TPC) in $\mathrm{mg}$ gallic acid equivalent (GAE)/g, DPPH antioxidant activity (AA) in $\mathrm{mg}$ butylated hy- droxyanisole (BHA)/g, db, both in $50 \%$ aqueous ethanolic extract, and monomeric anthocyanin content (MAC) in mg malvidin3glucoside $(\mathrm{M} 3 \mathrm{G}) / \mathrm{g}$, db were measured for different portions (triplicate) of the powder before and after mixing. The pulp powder contained $26.19 \pm 0.45$ TPC, $23.79 \pm 0.35$ AA and 9.96 \pm 0.16 $\mathrm{MAC}$, whereas for kernel powder the values were $53.95 \pm 0.26 \mathrm{TPC}$ and $57.97 \pm 0.31 \mathrm{AA}$.

\subsection{Mixing of jamun pulp and seed kernel powder}

Pulp powder and kernel powder, in different proportions, were mixed by tumbling (10 min), followed by wire whipping (10 min) using a hand blender (Anjali Marketing \& Research Centre, Mumbai, India). Based on a nine-point hedonic rating of appearance, aroma, taste, mouthfeel and overall acceptability of the mixtures by 27 semi-trained panellists, a suitable proportion was selected (Ranganna, 1986). The selected mixture, referred to as JP, was double packaged in $\mathrm{LDPE}$ pouches, and stored at $-30^{\circ} \mathrm{C}$ for further studies.

\subsection{Determination and modelling of EMC}

The isopiestic vapour transfer technique was used to determine EMC (Chowdhury \& Das, 2010). Around one gram of JP was placed in a weighing bottle (in triplicate) and the bottles placed in eight vacuum desiccators, each containing a saturated solution of a salt (section 3.2) to maintain RH (10-90\%). The desiccators were placed in an incubator at $25{ }^{\circ} \mathrm{C}$. After equilibration (about five days based on preliminary experiments), the mass of the bottles plus samples were noted. These were then dried overnight at $105 \pm 1{ }^{\circ} \mathrm{C}$ to determine the dry mass of JP. The $\operatorname{EMC~}(\%, \mathrm{db})$ was calculated using Eq. (1).

$$
E M C(\%)=\frac{W_{e q}-W_{d r y}}{W_{d r y}} \times 100
$$

where $\mathrm{W}_{e q}$ and $\mathrm{W}_{d r y}$ are the masses of equilibrated and dried powder.

The experiment was similarly carried out at 35 
${ }^{\circ} \mathrm{C}$ and $45{ }^{\circ} \mathrm{C}$.

Five MSI models (Table 1) were used to fit the experimental EMCs using non-linear regression analysis (Microsoft Excel 2013). In the models, $\mathrm{M}$ represents $\mathrm{EMC}(\%, \mathrm{db})$ of the sample, and $\mathrm{a}_{w}$ is its water activity. $\mathrm{A}, \mathrm{B}$ and $\mathrm{C}$ are the model specific coefficients. In the GAB model, A, B and $\mathrm{C}$, respectively, represent the monolayer moisture content, heat of the first layer sorption and heat of the multilayer sorption.

Model fitting parameters, including co-efficient of determination $\left(\mathrm{r}^{2}\right)$, root mean square error (RMSE) (Eq. 2), mean residual error (MRE \%) (Eq. 3) and residual plot (a plot of $\left(\mathrm{M}_{i}\right.$ $\mathrm{M}_{p i}$ ) versus $\mathrm{M}_{i}$ for respective $\mathrm{a}_{w} \mathrm{~s}$ ) were evaluated. The $\mathrm{r}^{2}$ was evaluated through regression analysis.

$$
\begin{gathered}
R M S E=\left[\frac{1}{n} \times \sum_{i=1}^{n}\left(M_{i}-M_{p i}\right)^{2}\right]^{1 / 2} \\
M R E(\%)=\frac{100}{n} \sum_{i=1}^{n}\left|\frac{M_{i}-M_{p i}}{M_{i}}\right|
\end{gathered}
$$

where $\mathrm{M}_{i}$ and $\mathrm{M}_{p i}$ are the experimental and predicted values of EMC and $n$ is the number of experimental runs.

To be a good fit, the model should have a $\mathrm{r}^{2}$ close to 1 , RMSE close to 0 , MRE below $10 \%$ and randomness in the residual plot where the data points are distributed in a horizontal band around zero (Lomauro, Bakshi, \& Chen, 1985).

\subsection{Net isosteric heat of sorption $\left(\mathbf{q}_{s t}\right)$}

The $\mathrm{q}_{s t}\left(\mathrm{~kJ} . \mathrm{mol}^{-1}\right)$ was estimated using the Clausius-Clapeyron equation (Eq. 4).

$$
\ln a_{w}=-\frac{q_{s t}}{R T}+Z
$$

where $\mathrm{R}$ is the universal gas constant $\left(8.314 \times 10^{-3} \mathrm{~kJ} . \mathrm{mol}^{-1} . \quad \mathrm{K}^{-1}\right), \quad \mathrm{T}$ is the absolute temperature in Kelvin $(\mathrm{K})$ and $\mathrm{Z}$ is the integration constant.

Using the best fit model, $\mathrm{a}_{w}$ values were evaluated, at any particular moisture content, for different temperatures. The slope of the plot of $\ln \mathrm{a}_{w}$ versus $1 / \mathrm{T}$ gave the $\mathrm{q}_{s t}$ at that moisture content. This was repeated for different moisture contents to evaluate the effect of moisture content on $\mathrm{q}_{s t}$. The absolute value of $\mathrm{q}_{s t}$ was considered, as the sign of $\mathrm{q}_{s t}$ doesn't bear any physical interpretation (Chowdhury \& Das, 2010).

\section{$2.7 \quad$ Spreading pressure $(\Phi)$}

According to Igathinathane et al. (2007), spreading pressure, $\Phi\left(\mathrm{J} . \mathrm{m}^{-2}\right)$, was calculated using Eq. (5) as shown below.

$$
\Phi=\frac{K_{\beta} T}{A_{m}} \int_{0}^{a_{w}} \frac{M}{A a_{w}} d a_{w}
$$

where $\mathrm{K}_{\beta}$ is the Boltzmann constant $(1.380 \times$ $\left.10^{-23} \mathrm{~J} . \mathrm{K}^{-1}\right), \mathrm{A}_{m}$ is the surface area of a water molecule $\left(1.06 \times 10^{-19} \mathrm{~m}^{2}\right), \mathrm{M}$ is the EMC and $\mathrm{A}$ is the monolayer moisture content.

Since the integral cannot be evaluated at $\mathrm{a}_{w}=$ 0.0, the lower limit in Eq. (5) was considered as 0.05. After substituting the GAB equation (Table 1) in Eq. (5) and integrating, spreading pressure for the range of $\mathrm{a}_{w}$ from 0.05 to $\mathrm{a}_{w}$ was calculated using Eq. (6) (Lago, Liendo-Cardenas, \& Zapata Norena, 2013).

$$
\Phi=\frac{K_{\beta} T}{A_{m}} \ln \left[\frac{1+B C a_{w}-C a_{w}}{1-C a_{w}}\right]_{0.05}^{a_{w}}
$$

The integral covering the $\mathrm{a}_{w}$ range from 0.00 to 0.05 was evaluated (Eq. 7) assuming a linear relationship (Henry's law) between M/A and $\mathrm{a}_{w}$ (Fasina, Ajibola, \& Tyler, 1999; Igathinathane et al., 2007).

$$
\Phi=\frac{K_{\beta} T M}{A_{m} A}
$$

Totalling the values of Eq. (6) and Eq. (7), the $\Phi$ corresponding to any temperature and $\mathrm{a}_{w}$ combination was produced. Spreading pressure versus $\mathrm{a}_{w}$ was plotted for different temperatures.

\subsection{Net integral enthalpy $\left(Q_{i n}\right)$}

Net integral enthalpy $\left(\mathrm{Q}_{i n}, \mathrm{~kJ} . \mathrm{mol}^{-1}\right)$ was evaluated (Eq. 8) in a comparable methodology to that of the $\mathrm{q}_{s t}$ but at constant $\Phi$ instead of constant moisture content:

$$
\left|\frac{d\left[\ln a_{w}\right]}{d[1 / T]}\right|_{\Phi} \approx-\frac{Q_{i n}}{R}
$$


Table 1: Sorption models used for fitting experimental EMC data of JP

\begin{tabular}{lll}
\hline Model & Equation & Reference \\
\hline Peleg & $\mathrm{M}=\mathrm{A}\left(\mathrm{a}_{w}\right)^{B}+\mathrm{C}\left(\mathrm{a}_{w}\right)^{D}$ & Chowdhury and Das (2010) \\
Guggenheim-Anderson-de-Boer $(\mathrm{GAB})$ & $\mathrm{M}=\mathrm{ABCa} w /\left[\left(1-\mathrm{Ca} \mathrm{a}_{w}\right)\left(1-\mathrm{Ca}_{w}+\mathrm{BCa}_{w}\right)\right]$ & Ibanoglu, Kaya, and Kaya (1999) \\
Oswin & $\mathrm{M}=\mathrm{A}\left[\mathrm{a}_{w} /\left(1-\mathrm{a}_{w}\right)^{B}\right]$ & de Santana et al. (2015) \\
Henderson & $\mathrm{M}=\left[-\ln \left(1-\mathrm{a}_{w}\right) / \mathrm{A}\right]^{1 / B}$ & de Santana et al. (2015) \\
Halsey & $\mathrm{M}=\left[-\mathrm{A} / \ln \left(\mathrm{a}_{w}\right)\right]^{1 / B}$ & Chowdhury and Das (2010) \\
\hline
\end{tabular}

From the plot of $\Phi$ versus $\mathrm{a}_{w}$ at various temperatures, $\mathrm{a}_{w}$ values at any particular $\Phi$ were obtained through interpolation (Igathinathane et al., 2007). The slope of the plot of $\ln \mathrm{a}_{w}$ versus $1 / \mathrm{T}$ at constant $\Phi$ produced the $\mathrm{Q}_{\text {in }}$. Next, moisture contents at the interpolated $\mathrm{a}_{w}$ values were calculated using the best fit MSI equation. Thus, at three temperatures, there were three moisture contents for each $\Phi$, and the geometric mean moisture content was derived. $Q_{\text {in }}$ versus geometric mean moisture content was then plotted.

\subsection{Net integral entropy $\left(\mathrm{S}_{i n}\right)$}

Net integral entropy $\left(\mathrm{S}_{i n}, \mathrm{~kJ} \cdot \mathrm{mol}^{-1} \cdot \mathrm{K}^{-1}\right)$ was calculated using the following equation (Eq. 9) (Igathinathane et al., 2007).

$$
S_{i n}=\frac{-Q_{i n}}{T}-R \ln \left(a_{W}^{*}\right)
$$

where $\mathrm{a}_{w}^{*}$ is the geometric mean water activity at constant $\Phi$. The temperature term T of Eq. (9) was interpolated linearly for $\mathrm{a}_{w}^{*}$ from the $\mathrm{T}$ versus $\mathrm{a}_{w}$ data for a given $\Phi . \mathrm{S}_{i n}$ was then plotted against moisture content.

\subsection{Statistical analyses}

The arithmetic mean of the replicated values of different observations and the respective standard deviation (SD) were evaluated. Geometric means, in calculations of thermodynamic parameters, were also evaluated. The mean values were used in analysis of variance ( $\mathrm{F}$ test, one way) relating to parametric variation (treatment effect) followed by evaluation of least significant differ- ence (LSD at $\mathrm{P}<0.05$, in cases of positive $\mathrm{F}$ test), paired t-test $(\mathrm{P}<0.05)$, and model fitting.

\section{Results and discussion}

\subsection{Mixing of pulp and kernel powder}

In JP, the sensory quality of pulp is most desirable, as the kernel powder possesses bitter taste. The results of sensory evaluation on mixing of pulp and kernel powder are shown in Table 2. It is seen that aroma, taste and overall acceptability of the pulp powder were negatively affected ( $\mathrm{F}$ test positive) by addition of kernel powder, whereas appearance and mouthfeel remained unaffected. The corresponding LSD value (included in the same table) indicates that deterioration of the pulp powder starts at $6 \%$ addition of kernel powder for aroma and $4 \%$ addition of kernel powder for both taste and overall acceptability. At $2 \%$ addition, none of these qualities were affected. Therefore, $2 \%$ kernel addition was finally selected for the production of JP. The produced powder (JP) is shown in Figure 1, which contained TPC, AA and MAC values of $27.25 \pm 0.19$ (mg GAE/g, db), 25.04 \pm 0.07 (mg BHA/g, db) and 9.77 $\pm 0.22(\mathrm{mg} \mathrm{M} 3 \mathrm{G} / \mathrm{g}, \mathrm{db})$ respectively. These values are statistically different (t-test) from those of pulp powder. Thus, addition of $2 \%$ kernel powder led to an increase in TPC and AA values of the pulp powder by 4$5 \%$, while the MAC value was less $(\sim 2 \%)$. Furthermore, the standard deviation of these functionalities was within $0.2-2 \%$. Since low standard deviation is an indication of powder mixing, the JP can be considered to have good overall uniformity. 
Moisture Sorption and Thermodynamic Properties of Syzygium cumini Powder $\mid 117$

Table 2: Sensory evaluation of the mixed powder containing different proportions of pulp and kernel powder

\begin{tabular}{lcccccc}
\hline $\begin{array}{l}\text { Mixed powder constituents } \\
\text { (\%, w/w, db) }\end{array}$ & & \multicolumn{3}{c}{ Mean \pm SD } \\
Pulp powder & Kernel powder & Appearance $\Psi$ & Aroma & Taste & Mouthfeel $\Psi$ & $\begin{array}{c}\text { Overall } \\
\text { acceptability }\end{array}$ \\
\hline 100 & 0 & $7.56 \pm 0.70$ & $7.63 \pm 0.97^{\#}$ & $7.43 \pm 0.72^{\#}$ & $6.63 \pm 1.42$ & $7.67 \pm 0.64^{\#}$ \\
98 & 2 & $7.56 \pm 0.70$ & $7.74 \pm 0.82^{\# *}$ & $7.46 \pm 0.80^{\#}$ & $6.80 \pm 0.94$ & $7.56 \pm 0.66^{\#}$ \\
96 & 4 & $7.52 \pm 0.80$ & $7.26 \pm 1.32^{\# *}$ & $6.39 \pm 0.75^{*}$ & $6.52 \pm 1.53$ & $6.50 \pm 0.71$ \\
94 & 6 & $7.20 \pm 1.11$ & $6.91 \pm 1.58^{* \$}$ & $6.00 \pm 0.77^{*}$ & $6.52 \pm 1.42$ & $5.82 \pm 0.84$ \\
92 & 8 & $7.13 \pm 0.89$ & $6.83 \pm 1.39^{\$ !}$ & $5.56 \pm 0.74$ & $6.22 \pm 1.31$ & $5.39 \pm 0.83$ \\
90 & 10 & $7.04 \pm 1.29$ & $6.74 \pm 1.68^{\$ !}$ & $4.93 \pm 0.84$ & $6.06 \pm 1.30$ & $4.74 \pm 0.90$ \\
\hline LSD & \multicolumn{2}{c}{$\mathbf{0 . 7 1}$} & $\mathbf{0 . 4 1}$ & - & $\mathbf{0 . 4 1}$ \\
\hline
\end{tabular}

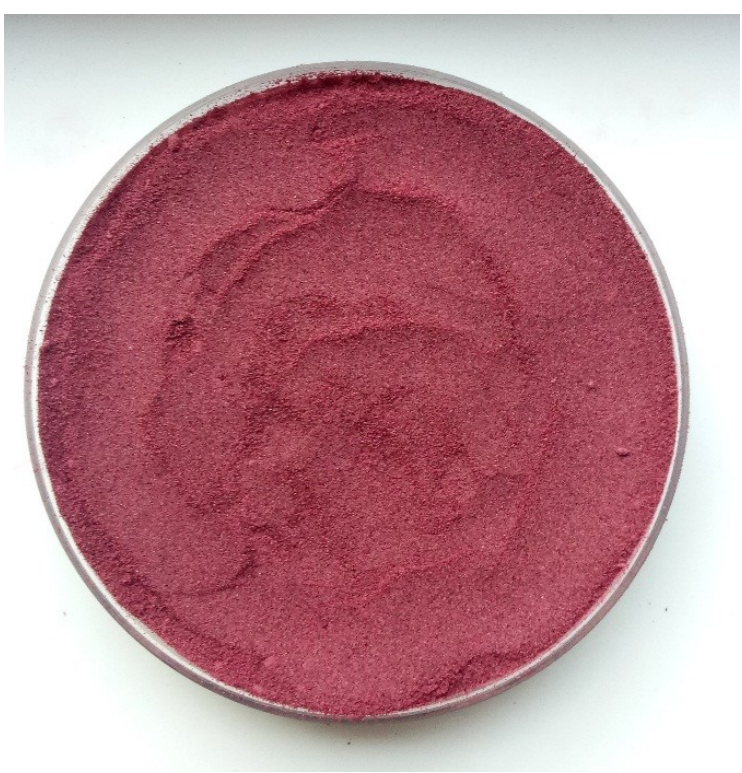

Figure 1: Jamun powder (JP) having particle size below $212 \mu \mathrm{m}$

\subsection{Equilibrium moisture content (EMC) of JP}

The mean $\mathrm{EMCs} \pm \mathrm{SD}$ of JP for varying $\mathrm{RH}$ (with different salts) at $25^{\circ} \mathrm{C}, 35^{\circ} \mathrm{C}$ and $45^{\circ} \mathrm{C}$ are presented in Table 3. One-way ANOVA, at any temperature, resulted in a positive F-test $(p<0.05)$ indicating that EMC is significantly dependent on the $\mathrm{RH}$ of the environment ( $\mathrm{a}_{w}$ of the sample). LSD values further confirm that at all three temperatures, EMC increased with increase in $\mathrm{RH} / \mathrm{a}_{w}$, except for the range of $\mathrm{a}_{w}$ from 0.113 to 0.215 at $35{ }^{\circ} \mathrm{C}$. Thus, the sorption characteristics show a direct relationship between $\mathrm{a}_{w}$ and EMC.

\subsection{Fitting of sorption model}

Table 4 summarizes the results of regression analysis for fitting the EMC data to various models, and the model fitting criteria. All five models produced $\mathrm{r}^{2}$ close to 1 at all three temperatures. Considering MRE\%, RMSE and residual plot requirements, the Peleg model was found to be the most suitable. Except for a RMSE value at 25 ${ }^{o} \mathrm{C}$, the GAB model satisfied all the selection criteria at all three temperatures. The Oswin model suited all criteria better at $35{ }^{\circ} \mathrm{C}$. At $25{ }^{\circ} \mathrm{C}$ it indicated a MRE $>15 \%$ and at $45{ }^{\circ} \mathrm{C}$ there was a residual plot pattern. The Halsey model was more satisfactory at $45{ }^{\circ} \mathrm{C}$. At $25{ }^{\circ} \mathrm{C}$ it indicated a pattern shape and at $35{ }^{\circ} \mathrm{C}$ the $\mathrm{MRE}$ was $\approx$ $10 \%$. The Henderson model produced a pattern plot at $35{ }^{\circ} \mathrm{C}$ and $45{ }^{\circ} \mathrm{C}$, and a $>10 \%$ MRE at all the temperatures. Hence, the Peleg model can be considered as the best fit, followed by the GAB model for EMCs of microwave-convective hot air dried JP within the temperature range of 25-45 ${ }^{o} \mathrm{C}$. The Peleg model was found to be suitable by de Santana et al. (2015) for freeze dried jamun 
118| Dey Paul and Das

Table 3: The mean equilibrium moisture content (EMC) along with standard deviation (SD) of jamun powder (JP) for varying $\mathrm{a}_{w}$ at $25{ }^{\circ} \mathrm{C}, 35^{\circ} \mathrm{C}$ and $45^{\circ} \mathrm{C}$

\begin{tabular}{|c|c|c|c|c|c|c|}
\hline \multirow{2}{*}{$\begin{array}{l}\text { Salt solutions used } \\
\text { for generation of } \mathbf{a}_{w}\end{array}$} & \multicolumn{2}{|r|}{$25{ }^{\circ} \mathrm{C}$} & \multicolumn{2}{|r|}{$35{ }^{\circ} \mathrm{C}$} & \multicolumn{2}{|r|}{$45^{\circ} \mathrm{C}$} \\
\hline & $\mathbf{a}_{w}$ & $\begin{array}{c}\text { EMC } \\
(\%, \mathrm{db}) \pm \mathrm{SD}^{\Psi}\end{array}$ & $\mathbf{a}_{w}$ & $\begin{array}{c}\text { EMC } \\
(\%, \mathrm{db}) \pm \mathrm{SD}^{\Psi}\end{array}$ & $\mathbf{a}_{w}$ & $\begin{array}{c}\text { EMC } \\
(\%, \mathrm{db}) \pm \mathrm{SD}^{\Psi}\end{array}$ \\
\hline Lithium chloride $(\mathrm{LiCl})$ & 0.114 & $4.43 \pm 0.36$ & 0.113 & $3.38 \pm 0.37^{\#}$ & 0.112 & $2.82 \pm 0.31$ \\
\hline Potassium acetate $\left(\mathrm{CH}_{3} \mathrm{COOK}\right)$ & 0.237 & $6.09 \pm 0.27$ & 0.215 & $4.73 \pm 0.64^{\#}$ & 0.197 & $4.57 \pm 0.27$ \\
\hline Magnesium chloride $\left(\mathrm{MgCl}_{2}\right)$ & 0.327 & $9.98 \pm 0.41$ & 0.320 & $7.51 \pm 0.44$ & 0.311 & $6.73 \pm 0.11$ \\
\hline Potassium carbonate $\left(\mathrm{K}_{2} \mathrm{CO}_{3}\right)$ & 0.443 & $12.84 \pm 0.24$ & 0.436 & $10.72 \pm 0.94$ & 0.429 & $10.51 \pm 0.27$ \\
\hline Magnesium nitrate $\left\{\mathrm{Mg}\left(\mathrm{NO}_{3}\right)_{2}\right\}$ & 0.536 & $16.52 \pm 0.47$ & 0.515 & $14.25 \pm 2.49$ & 0.497 & $12.07 \pm 0.26$ \\
\hline Sodium nitrate $\left(\mathrm{NaNO}_{3}\right)$ & 0.742 & $30.59 \pm 0.53$ & 0.720 & $27.12 \pm 1.65$ & 0.699 & $24.89 \pm 0.42$ \\
\hline Sodium chloride $(\mathrm{NaCl})$ & 0.752 & $32.20 \pm 0.24$ & 0.748 & $29.64 \pm 1.37$ & 0.745 & $31.16 \pm 0.84$ \\
\hline \multirow[t]{2}{*}{ Potassium chloride $(\mathrm{KCl})$} & 0.855 & $43.17 \pm 0.19$ & 0.822 & $41.19 \pm 0.64$ & 0.791 & $40.09 \pm 0.08$ \\
\hline & LSD & 0.62 & LSD & 2.19 & LSD & 0.68 \\
\hline
\end{tabular}

pulp isotherms.

\subsection{Moisture sorption isotherms}

Figure 2 illustrates the MSIs of JP at $25{ }^{\circ} \mathrm{C}$, $35{ }^{\circ} \mathrm{C}$ and $45^{\circ} \mathrm{C}$, as fitted by the Peleg model. Depending on slope, the MSIs can be divided into three zones. At any temperature, the EMC of JP increased relatively slowly at $\mathrm{a}_{w} \mathrm{~s}$ within $\approx 0.1-0.5$, compared to the region beyond 0.5 $\mathrm{a}_{w}$ where sharp increases were observed. Thus, shape of the isotherms indicates Type III behaviour, which is a characteristic of foods rich in soluble components (Rizvi, 2014). JP contains about $45 \%$ reducing sugars $(\mathrm{db})$ with glucose itself amounting to about 19\% (db) (obtained in different experiments not included here). The observed trend of moisture sorption can be attributed to the dissolution tendency of fruit sugars in the absorbed moisture (Maroulis, Tsami, Marinos-Kouris, \& Saravacos, 1988). A similar kind of sorption trend was also noticed for sugarrich foods such as tomato pulp powder (Goula, Karapantsios, Achilias, \& Adamopoulos, 2008), grapes, apples (Kaymak-Ertekin \& Gedik, 2004) and orange juice powder (Sormoli \& Langrish, 2015). Since EMC underwent a sharp increase beyond $0.5 \mathrm{a}_{w}$, it can be said that, at $\mathrm{RH}$ higher than $50 \%$, JP needs special storage conditions to inhibit several possible degradation reactions. da Silva, Meller da Silva, and Pena (2008) also voiced a similar opinion in their study.
In Figure 2, the EMC decreased with increasing temperature $\left(25^{\circ} \mathrm{C}>35{ }^{\circ} \mathrm{C}>45{ }^{\circ} \mathrm{C}\right)$ at any value of $\mathrm{a}_{w}$ up to about 0.75 , with slopes being higher than that exhibited below $0.5 \mathrm{a}_{w}$. The decrease in the total number of active sites as a consequence of temperature induced physical/chemical changes may result in the fall of EMC (Chowdhury \& Das, 2012; Muzaffar \& Kumar, 2016). At increased temperatures, water molecules because of their activation at higher energy levels gain higher mobility, become unstable and break away from the binding sites, thereby causing a reduction in EMC, as explained by Menkov and Durakova (2007). According to de Santana et al. (2015) and Al-Muhtaseb et al. (2002), the water vapour pressure (WVP) on powder surfaces increases at higher temperatures, allowing the water molecules to get detached from the binding sites. Interestingly for $\mathrm{a}_{w}$ higher than 0.75 , the increase in EMC with $\mathrm{a}_{w}$ is even higher than for the previously displayed regions. Moreover, a crossover is seen so that the EMCs follow the order: $45{ }^{\circ} \mathrm{C}>35{ }^{\circ} \mathrm{C}>25{ }^{\circ} \mathrm{C}$. As described by Basu, Shivhare, and Muley (2013) and Labuza and Altunakar (2007), such crossover at high water activity is mainly due to increased solubility of sugar and dissolution of new solutes at higher temperatures. Also, at high water activity the soluble components absorb more water, which is further accentuated by the temperature (Basu et al., 2013). 
Moisture Sorption and Thermodynamic Properties of Syzygium cumini Powder |119

Table 4: Model coefficients and error terms for different sorption models

\begin{tabular}{|c|c|c|c|c|c|c|c|c|c|}
\hline Temp $\left({ }^{\circ} \mathbf{C}\right)$ & EMC Model & $\mathbf{A}$ & B & $\mathrm{C}$ & D & $\mathbf{r}^{2}$ & RMSE & MRE (\%) & Residual Plot \\
\hline \multirow{5}{*}{25} & Peleg & 30.3963 & 0.9989 & 36.8762 & 5.0221 & 0.9946 & 0.8827 & 7.8715 & Random \\
\hline & GAB & 11.1246 & 5.2765 & 0.8781 & - & 0.9874 & 1.4263 & 9.1236 & Random \\
\hline & Oswin & 16.4801 & 0.5272 & - & - & 0.9844 & 1.8427 & 15.4206 & Random \\
\hline & Henderson & 0.0198 & 1.2322 & - & - & 0.9960 & 1.8681 & 12.4555 & Random \\
\hline & Halsey & 38.0501 & 1.4649 & - & - & 0.9740 & 2.4035 & 19.5301 & Pattern \\
\hline \multirow{5}{*}{35} & Peleg & 23.9963 & 0.9999 & 67.8792 & 5.9221 & 0.9875 & 0.4133 & 5.1785 & Random \\
\hline & GAB & 9.5502 & 2.9603 & 0.9584 & - & 0.9848 & 0.3629 & 4.8470 & Random \\
\hline & Oswin & 13.4154 & 0.7336 & - & - & 0.9858 & 0.3076 & 4.0173 & Random \\
\hline & Henderson & 0.0740 & 0.8542 & - & - & 0.9956 & 0.9373 & 10.6109 & Pattern \\
\hline & Halsey & 10.4390 & 1.0626 & - & - & 0.9765 & 0.8959 & 9.9953 & Random \\
\hline \multirow{5}{*}{45} & Peleg & 23.0082 & 0.9978 & 123.3597 & 7.3802 & 0.9802 & 0.2312 & 2.5248 & Random \\
\hline & GAB & 7.3339 & 3.9545 & 1.0452 & - & 0.9798 & 0.2416 & 2.0775 & Random \\
\hline & Oswin & 12.7807 & 0.8417 & - & - & 0.9905 & 0.6595 & 6.8383 & Pattern \\
\hline & Henderson & 0.0478 & 1.0028 & - & - & 0.9984 & 3.0425 & 10.5552 & Pattern \\
\hline & Halsey & 6.6982 & 0.9085 & - & - & 0.9837 & 0.3622 & 4.4701 & Random \\
\hline
\end{tabular}

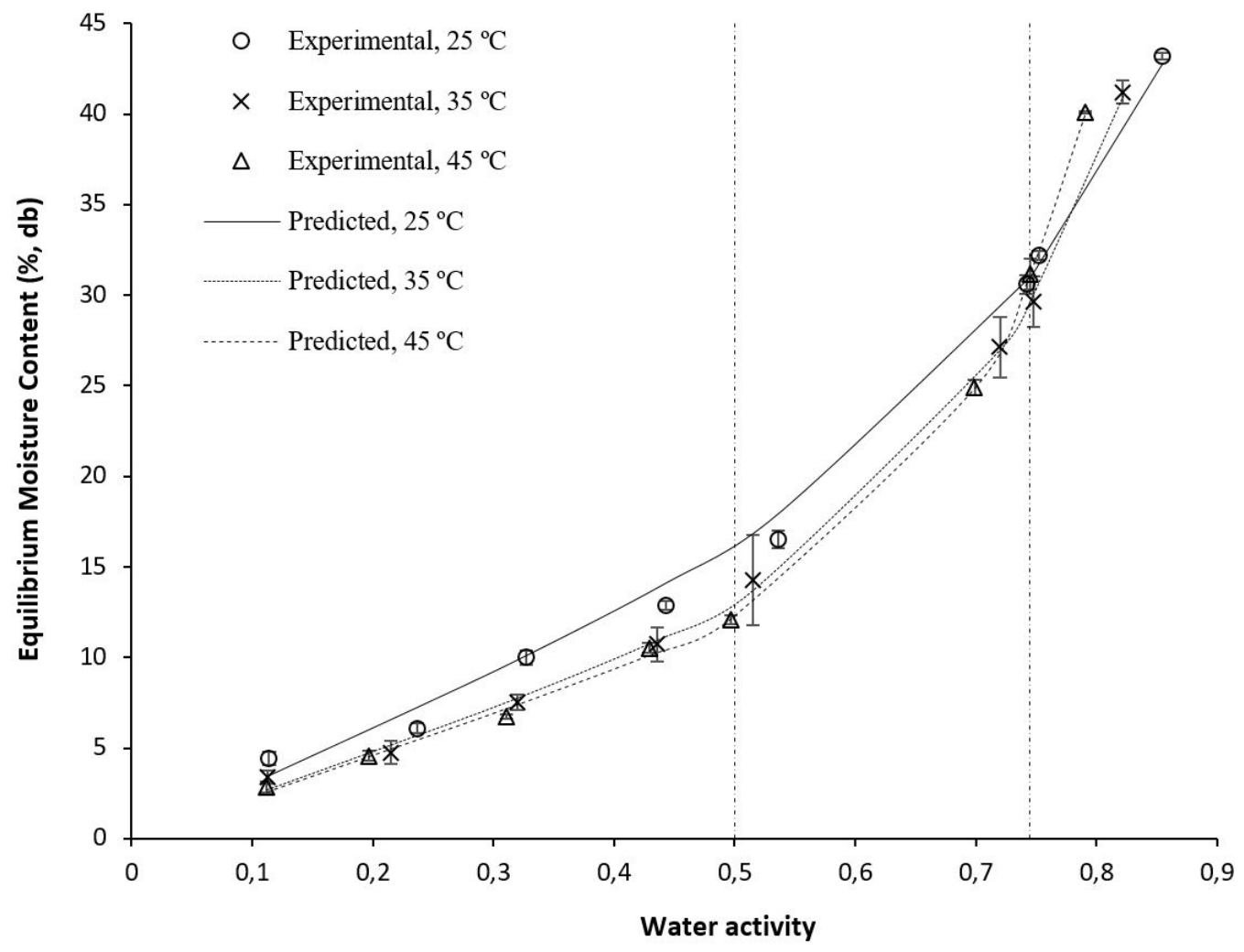

Figure 2: Effect of temperature on moisture sorption isotherm of JP as expressed by the Peleg model 


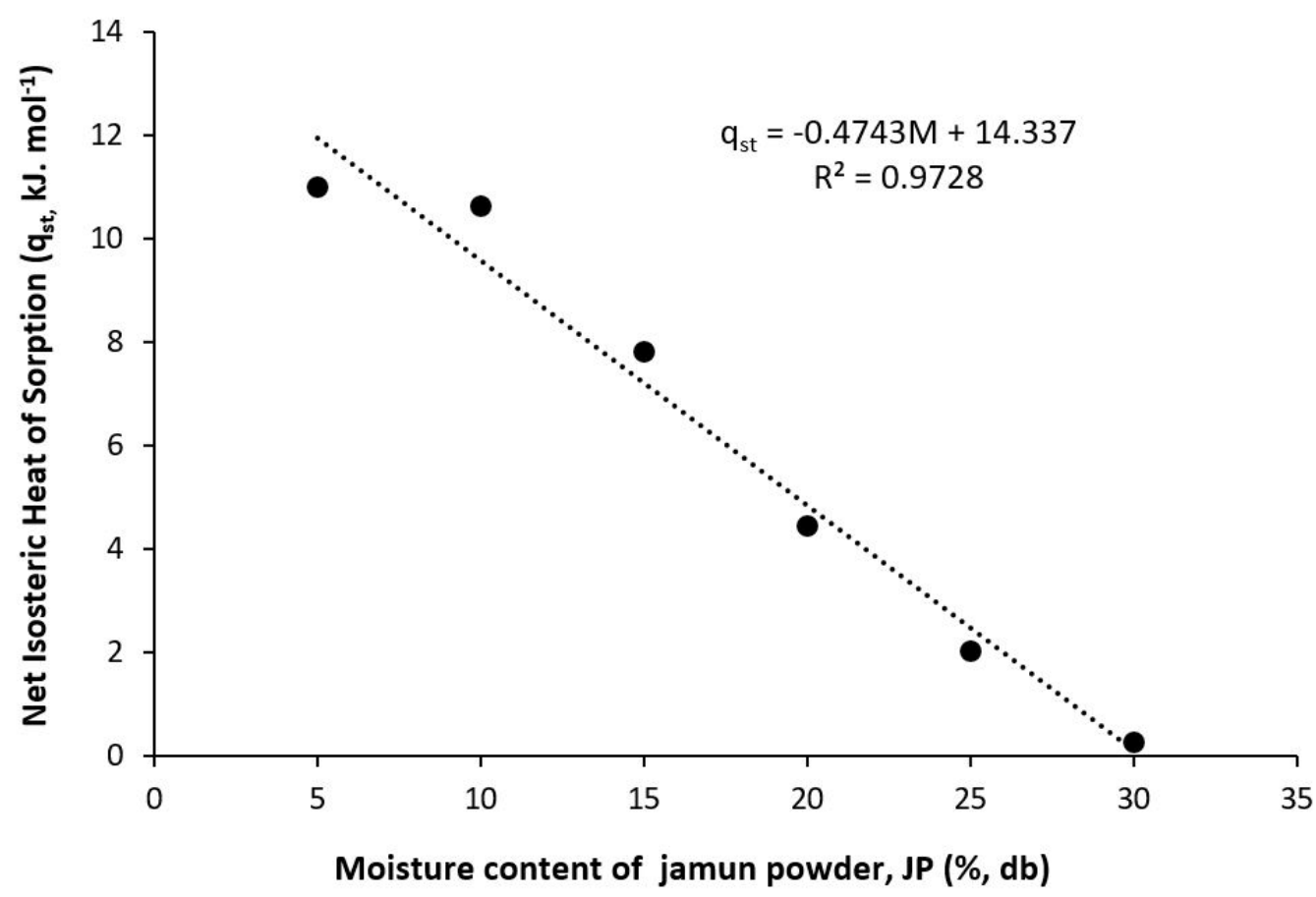

Figure 3: Variation in net isosteric heat of sorption $\left(\mathrm{q}_{s t}\right)$ of jamun powder $(\mathrm{JP})$ as a function of moisture content

\subsection{Net isosteric heat of sorption $\left(\mathbf{q}_{s t}\right)$}

The absolute value of $\mathrm{q}_{s t}$ (Eq. 4) of JP as a function of moisture content is represented in Figure 3. Mathematically, the trend is represented by the following linear relation (Eq. 10), and the resulting $\mathrm{r}^{2}$ justifies the appropriateness of the fit.

$$
q_{s t}=-0.4743 M+14.337 ; r^{2}=0.9728
$$

where $\mathrm{M}$ is the moisture content in $\%, \mathrm{db}$. Thus, the $\mathrm{q}_{s t}$ decreases with the increase in moisture content from $11.02 \mathrm{~kJ} \mathrm{~mol}^{-1}$ at $5 \%$ moisture to $0.27 \mathrm{~kJ} \mathrm{~mol}^{-1}$ at $30 \%$, thus approaching the heat of vaporization of pure water. The linear decreasing trend of $\mathrm{q}_{s t}$ was also observed by de Santana et al. (2015) for freeze dried jamun pulp and by Basu et al. (2013) for pectin. It may be worth mentioning that the maximum $\mathrm{q}_{s t}$ in this study is comparable with the value for orange juice powder $\left(9.05 \mathrm{~kJ} \mathrm{~mol}^{-1}\right)$ calculated by Sormoli and Langrish (2015).

Since higher the value of $\mathrm{q}_{s t}$ means higher is the degree of binding, the water molecules become tightly bound to the active sites on the surface of the JP at low moisture contents (Sormoli \& Langrish, 2015). As explained by Iglesias and Chirife (1982), sorption occurs initially at the most active sites involving higher interaction energy. As active sites get exhausted, moisture binding starts at less active sites producing less heat of sorption.

\subsection{Spreading pressure $(\Phi)$}

The value of $\Phi$ increases, almost linearly, with increase of $\mathrm{a}_{w}$ (Figure 4). At any $\mathrm{a}_{w}, \Phi$ decreases for an increase of temperature from 25 ${ }^{\circ} \mathrm{C}$ to $35{ }^{\circ} \mathrm{C}$. However, for further increase to 


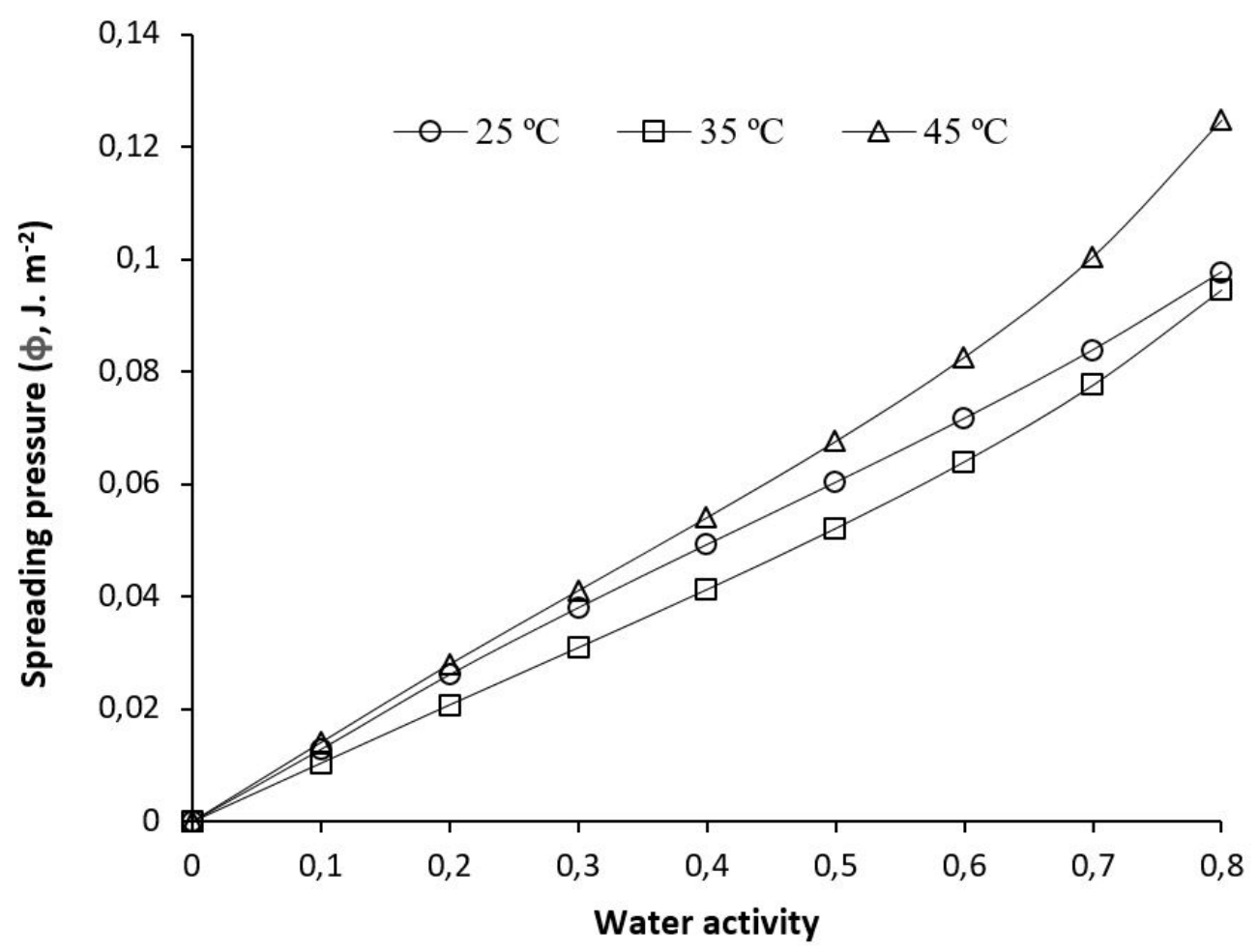

Figure 4: Variation in spreading pressure $(\Phi)$ with water activity $\left(\mathrm{a}_{w}\right)$ at $25{ }^{\circ} \mathrm{C}, 35{ }^{\circ} \mathrm{C}$ and $45^{\circ} \mathrm{C}$

$45{ }^{\circ} \mathrm{C}, \Phi$ increased to levels even higher than that at $25{ }^{\circ} \mathrm{C}$ and the differences in $\Phi$ further increased for $\mathrm{a}_{w}$ from 0.3 onwards. It may be stated that the effect of temperature on $\Phi$ is case specific, depending on composition of the sorbent. Depending on temperature, $\Phi$ may be increasing/decreasing/decreasing then increasing/increasing then decreasing (Aviara \& Ajibola, 2002; Lago et al., 2013; Al-Muhtaseb et al., 2004; Togrul \& Arslan, 2007). Similar observations, as for the present study, were reported for high amylose starch powder (Al-Muhtaseb et al., 2004) at $30-60{ }^{\circ} \mathrm{C}$, and walnut kernel (Togrul $\&$ Arslan, 2007) at $25-45{ }^{\circ} \mathrm{C}$.

Spreading pressure is the driving force for diffusion of moisture in a porous solid (Skaar \& Babiak, 1982). Torres, Moreira, Chenlo, and Vazquez (2012) explained that high spreading pressure values indicate a high affinity of water molecules for binding sites. This may lead to swelling in a high $\mathrm{RH}$ environment (discussed in section 3.7 ).

\subsection{Net integral enthalpy $\left(Q_{i n}\right)$}

Net integral enthalpy $\left(Q_{i n}\right)$ of bound water molecules initially decreases up to about $6 \%$ moisture content, and then increases for higher moisture content (Figure 5). The decreasing portion probably arises from the monolayer covering of JP (Fasina et al., 1999). At low moisture contents, water is preferentially adsorbed on the most accessible locations on the exterior surface of the solid. Following this, as less favourable sites are filled up, the $\mathrm{Q}_{\text {in }}$ then gradually declines till there is formation of multi layers of water (Al-Muhtaseb et al., 2004). With still higher moisture content gained in a higher $\mathrm{RH}$ atmo-

IJFS | April 2019 | Volume 8 | pages 111-126 


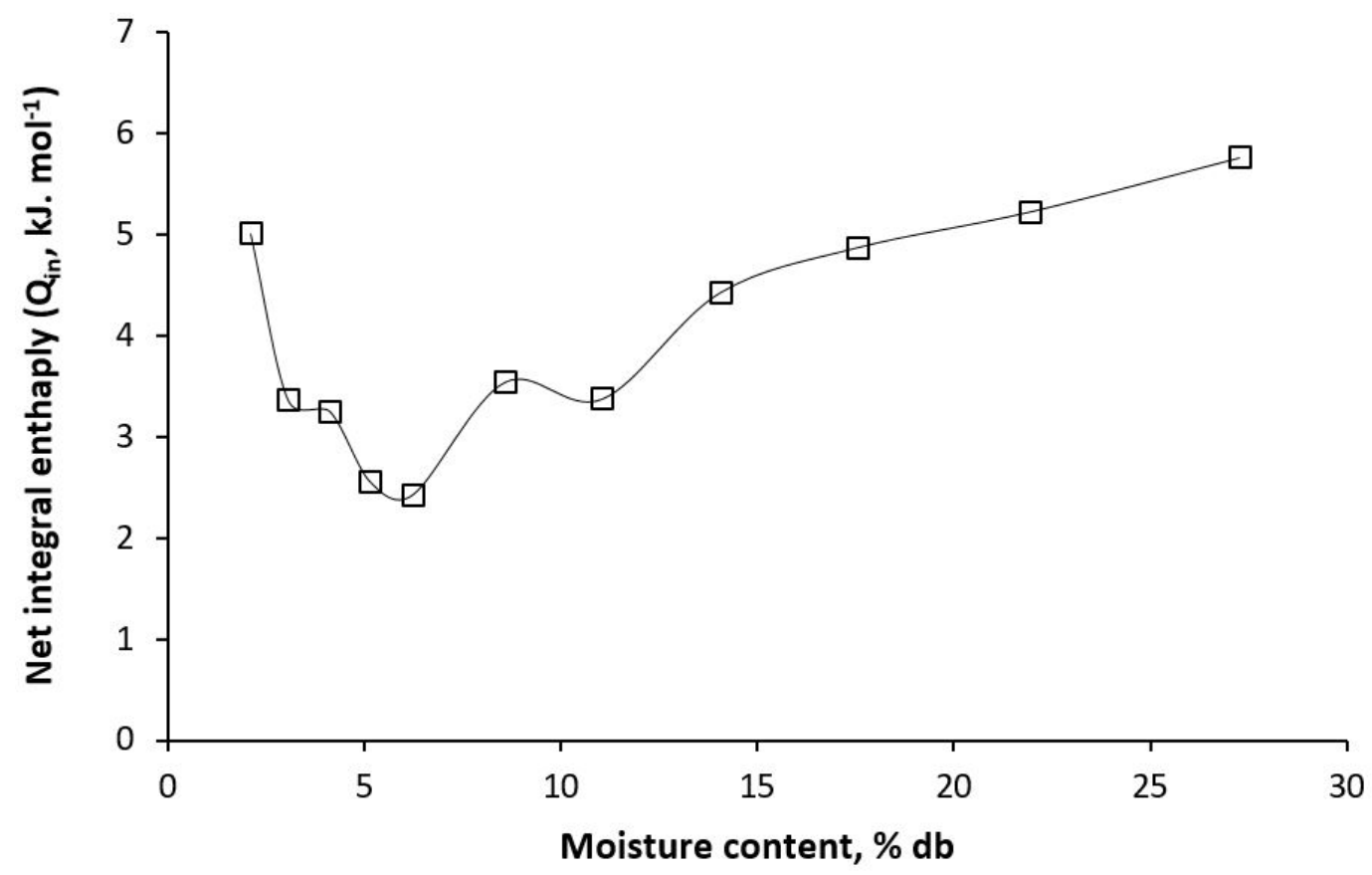

Figure 5: Variation in net integral enthalpy $\left(\mathrm{Q}_{i n}\right)$ of jamun powder $(\mathrm{JP})$ with moisture content

sphere, there is probably swelling of the powder with concomitant exposition of higher and higher energy binding sites that require increasingly higher $\mathrm{Q}_{\text {in }}$ involvement. Such a decreasing, followed by increasing, profile has been documented for mango skin (Ferreira de Souza et al., 2015) and orange peel (Villa-Velez, Ferreira de Souza, Ramos, Polachini, \& Telis-Romero, 2015). An increase in $Q_{i n}$ with increasing moisture content was also reported in studies on cassava (Aviara \& Ajibola, 2002) and potato and sweet potato flakes (Lago et al., 2013). In the case of walnuts kernels, the $Q_{i n}$ increased slightly with increasing moisture content and then remained constant (Togrul \& Arslan, 2007).

\subsection{Net integral enthalpy $\left(\mathrm{S}_{i n}\right)$}

Net integral entropy $\left(\mathrm{S}_{i n}\right)$ of the adsorbed water molecules was found to decrease continually with moisture content of JP (Figure 6). The loss in entropy, in general, indicates the loss of ro- tational freedom or randomness of the adsorbate molecules. On exposure to low $\mathrm{RH} / \mathrm{a}_{w}$, the easily available sites on the surface become filled, where in addition to ligand-substrate binding, lateral interactions in the adsorbed molecules also contribute to reduction in randomness (Aviara \& Ajibola, 2002). At increasingly higher RH, there is attainment of a higher EMC leading to structural transformation arising from solubilisation of ingredients and swelling of the powder which ultimately opens more and more sites to bind water molecules (McMinn \& Magee, 2003; Zhang, Bai, Zhao, \& Duan, 2016). In Figure 6, the maximum values of $S_{\text {in }}$ were found at the moisture content of around $1 \%(\mathrm{db})$ and can be considered as the zone of most energetic water molecules in the material. Following this, up to about $8 \% \mathrm{db}$ moisture content, $\mathrm{S}_{i n}$ decreased but remained in a positive zone. With $>8 \%$ moisture, the values were all negative. Similar profiles of $\mathrm{S}_{i n}$, covering both positive and negative zones, have been reported for moisture sorption of mango skin (Fer- 


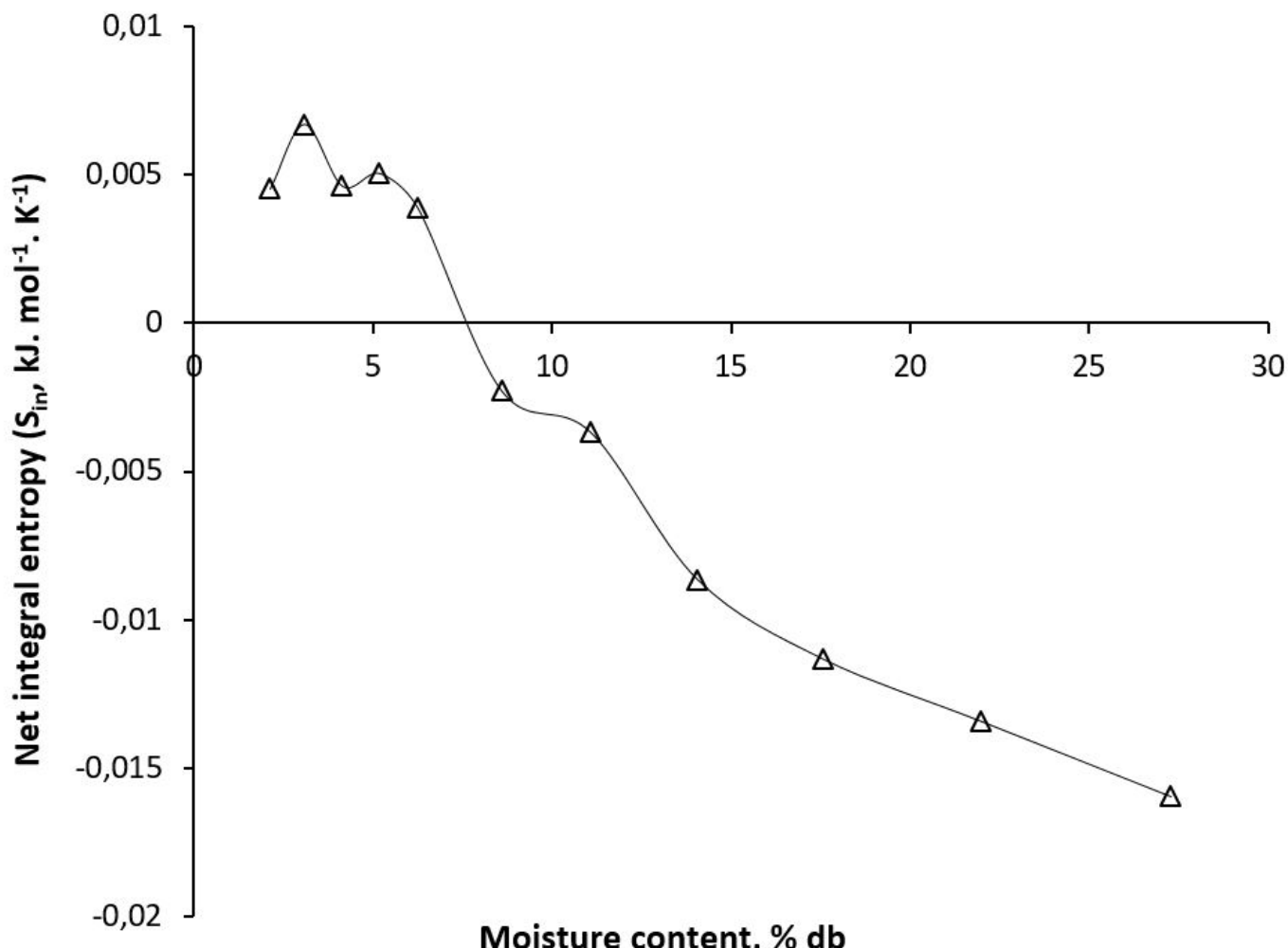

Figure 6: Variation in net integral entropy $\left(\mathrm{S}_{i n}\right)$ of jamun powder $(\mathrm{JP})$ with moisture content

reira de Souza et al., 2015) and gari (Aviara \& Ajibola, 2002). For mango skin adsorption, the negative value was also comparable to JP. Iglesias, Chirife, and Viollaz (1976) explained that negative values of $S_{i n}$ might be attributed to the existence of chemical adsorption and/or structural modifications of the adsorbent, while Rizvi (2014) attributed it to the fact that the products contain more polar groups, which bind water more strongly.

The minimum integral entropy zone corresponds to maximum stability of food products, since in this zone the water molecules are well accommodated and less available to take part in deteriorating reactions. In the case of $\mathrm{JP}$ where $\mathrm{S}_{i n}$ is gradually decreasing, probably due to structural modification (as mentioned above), the minimum integral entropy zone can be considered corresponding to the monolayer moisture content
(Ferreira de Souza et al., 2015). Thus from Table 4 , the safe moisture content may be in the zone of $7-11 \%$ (GAB monolayer value) for the temperature range of $45-25^{\circ} \mathrm{C}$.

\section{Conclusions}

Jamun seed kernel powder could be added to jamun pulp powder at a level of $2 \%(\mathrm{db})$ without affecting the sensorial acceptance of the pulp powder in the mixture, finally named as jamun powder (JP). The EMC of JP decreased with increasing temperature $\left(25{ }^{\circ} \mathrm{C}>35{ }^{\circ} \mathrm{C}>45{ }^{\circ} \mathrm{C}\right)$ at any constant value of $\mathrm{a}_{w}$ up to about 0.75 , and the Peleg model could satisfactorily describe the moisture sorption isotherms within $25-45^{\circ} \mathrm{C}$. Over the range of EMC from 5-30\%, the $\mathrm{q}_{s t}$ decreased linearly from $11.02 \mathrm{~kJ} . \mathrm{mol}^{-1}$ to $0.27 \mathrm{~kJ}$. $\mathrm{mol}^{-1}$. The $\Phi$ increased with increasing $\mathrm{a}_{w}$, and 
with respect to temperature it followed the order: $45{ }^{\circ} \mathrm{C}>25{ }^{\circ} \mathrm{C}>35{ }^{\circ} \mathrm{C}$. Net integral enthalpy $\left(\mathrm{Q}_{\text {in }}\right)$ displayed a decreasing trend till $6 \%$ moisture content of JP, followed by an increasing pattern thereafter for higher moisture contents. Net integral entropy $\left(\mathrm{S}_{i n}\right)$ was observed to decrease continuously with the increase in moisture content, and the monolayer moisture content 7$11 \%$ may be regarded as the safe moisture content zone for JP within the temperature range of $45-25{ }^{\circ} \mathrm{C}$.

\section{References}

Arslan, N., \& Togrul, H. (2005). Modelling of water sorption isotherms of macaroni stored in a chamber under controlled humidity and thermodynamic approach. Journal of Food Engineering, 69(2), 133-145. doi:10. 1016/j.jfoodeng.2004.08.004

Aviara, N. A., \& Ajibola, O. O. (2002). Thermodynamics of moisture sorption in melon seed and cassava. Journal of Food Engineering, 55(2), 107-113. doi:10.1016/ S0260-8774(02)00023-7

Basu, S., Shivhare, U. S., \& Muley, S. (2013). Moisture adsorption isotherms and glass transition temperature of pectin. Journal of Food Science and Technology-mysore, 50(3), 585-589. doi:10.1007/s13197-011$0327-\mathrm{y}$

Bhattacharya, M., Srivastav, P. P., \& Mishra, H. N. (2015). Thin-layer modeling of convective and microwave-convective drying of oyster mushroom (Pleurotus ostreatus). Journal of Food Science and Technologymysore, 52(4), 2013-2022. doi:10 . $1007 /$ s13197-013-1209-2

Biswal, S., Mohapatra, M., Panda, M. K., \& Dash, S. K. (2017). Moisture desorption isotherms of fresh jamun (Syzygium cumini) fruit. Indian Journal of Agricultural Research, 51(3), 267-271.

Chowdhury, T., \& Das, M. (2010). Moisture sorption isotherm and isosteric heat of sorption characteristics of starch based edible films containing antimicrobial preservative. International Food Research Journal, 17(3), 601-614. Retrieved from http://www.ifrj. upm . edu . my / $17 \%$ 5C \% 20(03 ) \%5C \% 202010/IFRJ-2010-601-614\%5C\%20India. pdf

Chowdhury, T., \& Das, M. (2012). Moisture sorption isotherm and isosteric heat of sorption of edible films made from blends of starch, amylose and methyl cellulose. International Food Research Journal, 19(4), 1669-1678. Retrieved from http://www.ifrj.upm.edu. my

da Silva, A. E., Meller da Silva, L. H., \& Pena, R. d. S. (2008). Hygroscopic behavior of acai and cupuacu powders. Ciencia $E$ Tecnologia De Alimentos, 28(4), 895-901. doi:10.1590/S0101-20612008000400020

Das, I., \& Arora, A. (2018). Alternate microwave and convective hot air application for rapid mushroom drying. Journal of Food Engineering, 223, 208-219. doi:10.1016/j . jfoodeng.2017.10.018

de Santana, R. F., de Oliveira Neto, E. R., Santos, A. V., Faria Soares, C. M., Lima, A. S., \& Cardoso, J. C. (2015). Water sorption isotherm and glass transition temperature of freeze-dried Syzygium cumini fruit (jambolan). Journal of Thermal Analysis and Calorimetry, 120(1), 519-524. doi:10.1007/ s10973-014-4014-x

Dey Paul, I., \& Das, M. (2017). Effect of maltodextrin, tricalcium phosphate and glycerol monostearate on moisture sorption characteristics of jamun (Syzygium cumini L.) pulp powder. In Proceedings of International Food Research Conference, held at Universiti Putra Malaysia, Malaysia. (p. 87). 25-27 July.

Fasina, O. O., Ajibola, O. O., \& Tyler, R. T. (1999). Thermodynamics of moisture sorption in winged bean seed and gari. Journal of Food Process Engineering, 22(6), 405-418. doi:10.1111/j.1745-4530.1999. tb00496.x

Ferrari, C. C., Marconi Germer, S. P., Alvim, I. D., Vissotto, F. Z., \& de Aguirre, J. M. (2012). Influence of carrier agents on the physicochemical properties of blackberry powder produced by spray drying. International Journal of Food Science and Technology, 47(6), 1237-1245. doi:10.1111/j. 1365-2621.2012.02964.x 
Moisture Sorption and Thermodynamic Properties of Syzygium cumini Powder $\mid 125$

Ferreira de Souza, S. J., Alves, A. I., Rufino Vieira, E. N., Gomez Vieira, J. A., Ramos, A. M., \& Telis-Romero, J. (2015). Study of thermodynamic water properties and moisture sorption hysteresis of mango skin. Food Science and Technology, 35(1), 157-166. doi:10.1590/1678-457X.6557

Goula, A. M., Karapantsios, T. D., Achilias, D. S., \& Adamopoulos, K. G. (2008). Water sorption isotherms and glass transition temperature of spray dried tomato pulp. Journal of Food Engineering, 85(1), 73-83. doi:10.1016/j.jfoodeng.2007.07.015

Horuz, E., Bozkurt, H., Karatas, H., \& Maskan, M. (2017). Drying kinetics of apricot halves in a microwave-hot air hybrid oven. Heat and Mass Transfer, 53(6), 2117-2127. doi:10.1007/s00231-017-1973-z

Ibanoglu, S., Kaya, S., \& Kaya, A. (1999). Evaluation of sorption properties of Turkish tarhana powder. Food / Nahrung, 43(2), 122-125. doi:10.1002 / (SICI) 15213803(19990301) 43:2〈122::AID-FOOD122〉 3.0.CO;2-3

Igathinathane, C., Womac, A. R., Sokhansanj, S., \& Pordesimo, L. O. (2007). Moisture sorption thermodynamic properties of corn stover fractions. Transactions of the Asabe, 50(6), 2151-2160. Annual Meeting of the American-Society-of-Agriculturaland-Biological-Engineers, Univ WisconsinMadison, Madison, WI, NOV 09-12, 2005.

Iglesias, H. A., \& Chirife, J. (1982). Handbook of food isotherms: Water sorption parameters for food and food components. (Chap. Mathematical description of isotherms, pp. 262-335). New York: Academic Press.

Iglesias, H. A., Chirife, J., \& Viollaz, P. (1976). Thermodynamics of water vapour sorption by sugar beet root. International Journal of Food Science \& Technology, 11(1), 91101. doi:10 . $1111 /$ j . 1365 - 2621 . 1976 . tb00705.x. eprint: https:// onlinelibrary. wiley.com/doi/pdf/10.1111/j.1365-2621. 1976.tb00705.x

Kamal, A. (2014). Phytochemical screening of Syzygium cumini seeds. Indian Journal of Plant Sciences, 3(4), 1-4.
Kapoor, A., \& Iqbal, H. (2013). Efficiency of tannase produced by Trichoderma harzianum MTCC 10841 in pomegranate juice clarification and natural tannin degradation. International Journal of Biotechnology and Bioengineering Research, 4 (6), 641-650.

Kaymak-Ertekin, F., \& Gedik, A. (2004). Sorption isotherms and isosteric heat of sorption for grapes, apricots, apples and potatoes. LWT - Food Science and Technology, 37(4), 429-438. doi:10.1016/j.lwt.2003.10. 012

Kumar, D., Prasad, S., \& Murthy, G. S. (2014). Optimization of microwave-assisted hot air drying conditions of okra using response surface methodology. Journal of Food Science and Technology-mysore, 51(2), 221232. doi:10.1007/s13197-011-0487-9

Labuza, T. P., \& Altunakar, B. (2007). Water activity in foods: Fundamentals and applications. In G. V. Barbosa-Canovas, J. A. J. Fontana, S. J. Schmidt, \& T. P. Labuza (Eds.), (Chap. Water activity prediction and moisture sorption isotherms, pp. 109-154). Blackwell Publishing, Oxford, UK.

Lago, C. C., Liendo-Cardenas, M., \& Zapata Norena, C. P. (2013). Thermodynamic sorption properties of potato and sweet potato flakes. Food and Bioproducts Processing, 91(C4), 389-395. doi:10.1016/j. fbp.2013.02.005

Lomauro, C. J., Bakshi, A. S., \& Chen, J. Y. (1985). Evaluation of food moisture sorption isotherm equations. Part I: Fruit, vegetable and meat products. $L W T$ - Food Science and Technology, 18, 111-117.

Maroulis, Z. B., Tsami, E., Marinos-Kouris, D., \& Saravacos, G. D. (1988). Application of the GAB model to the moisture sorption isotherms for dried fruits. Journal of Food Engineering, 7(1), 63-78. doi:10 . 1016/ 0260-8774(88)90069-6

McMinn, W. A. M., \& Magee, T. R. A. (2003). Thermodynamic properties of moisture sorption of potato. Journal of Food Engineering, 60(2), 157-165. doi:10.1016/ S0260-8774(03)00036-0

Menkov, N. D., \& Durakova, A. G. (2007). Moisture sorption isotherms of sesame flour at 
several temperatures. Food Technology and Biotechnology, 45(1), 96-100.

Monica, N., Dey Paul, I., \& Das, M. (2016). Microwave-convective hot air and vacuum drying of jamun seed powder. In H. N. Mishra, S. L. Srivastava, P. P. Srivastava, \& P. P. Tripathy (Eds.), Food process engineering and technology (Vol. Papers presented at International Conference on Emerging Technologies in Agricultural and Food Engineering, held at Indian Institute of Technology Kharagpur, India, 27-30 December, pp. 311-323). New Delhi: Excel India Publishers.

Al-Muhtaseb, A. H., McMinn, W. A. M., \& Magee, T. R. A. (2002). Moisture sorption isotherm characteristics of food products: A review. Food and Bioproducts Processing, 80(2), 118-128. doi:10.1205/ 09603080252938753

Al-Muhtaseb, A. H., McMinn, W. A. M., \& Magee, T. R. A. (2004). Water sorption isotherms of starch powders. part 2: Thermodynamic characteristics. Journal of Food Engineering, 62 (2), 135-142. doi:10. 1016/S0260-8774(03)00202-4

Muzaffar, K., \& Kumar, P. (2016). Moisture sorption isotherms and storage study of spray dried tamarind pulp powder. Powder Technology, 291, 322-327. doi:10.1016/ j.powtec.2015.12.046

Paul, I. D., \& Das, M. (2018). Effect of freeze, microwave-convective hot air, vacuum and dehumidified air drying on total phenolics content, anthocyanin content and antioxidant activity of jamun (Syzygium cumini L.) pulp. Journal of Food Science and Technology-mysore, 55(7), 2410-2419. doi:10.1007/s13197-018-3158-2

Ranganna, S. (1986). Handbook of analysis and quality control for fruit and vegetable products. (Chap. Sensory Evaluation, pp. 594645). Tata McGraw-Hill Education.

Rizvi, S. S. H. (2014). Thermodynamic properties of foods in dehydration. In Engineering properties of foods, third edition (pp. 359435). CRC Press.

Schiffmann, R. F. (1992). Microwave processing in the US food industry. Food Technology.
Sehwag, S., \& Das, M. (2015). Nutritive, therapeutic and processing aspects of jamun, Syzygium cuminii (L.) skeels-an overview. Natural Product Radiance, 5, 295-307.

Sehwag, S., \& Das, M. (2016). Composition and antioxidant potential of jamun (Syzygium cumini L.) from eastern india. Asian Journal of Biochemical and Pharmaceutical Research, 6, 106-121.

Sharma, G. P., \& Prasad, S. (2001). Drying of garlic (allium sativum) cloves by microwave-hot air combination. Journal of Food Engineering, 50(2), 99-105. doi:10. 1016/S0260-8774(00)00200-4

Skaar, C., \& Babiak, M. (1982). A model for bound-water transport in wood. Wood Science and Technology, 16(2), 123-138. doi:10.1007/BF00351098

Sormoli, M. E., \& Langrish, T. A. G. (2015). Moisture sorption isotherms and net isosteric heat of sorption for spray-dried pure orange juice powder. LWT - Food Science and Technology, 62 (1, 2, SI), 875-882. doi:10.1016/j.lwt.2014.09.064

Togrul, H., \& Arslan, N. (2007). Moisture sorption isotherms and thermodynamic properties of walnut kernels. Journal of Stored Products Research, 43(3), 252-264. doi:10. 1016/j.jspr.2006.06.006

Torres, M. D., Moreira, R., Chenlo, F., \& Vazquez, M. J. (2012). Water adsorption isotherms of carboxymethyl cellulose, guar, locust bean, tragacanth and xanthan gums. Carbohydrate Polymers, 89(2), 592-598. doi:10.1016/j.carbpol.2012.03.055

Villa-Velez, H. A., Ferreira de Souza, S. J., Ramos, A. P., Polachini, T., \& TelisRomero, J. (2015). Thermodynamic properties of water adsorption from orange peels. Journal of Bioenergy and Food Science, 2(2), 72-81. doi:10.18607/jbfs.v2i2. 32

Zhang, H., Bai, Y., Zhao, X., \& Duan, R. (2016). Water desorption isotherm and its thermodynamic analysis of glutinous rice flour. American Journal of Food Technology, 11(4), 115-124. Retrieved from 10. 3923/ajft.2016.115.124 